\title{
Portuguese Wood Pellets Market: Organization, Production and Consumption Analysis
}

\author{
Leonel J. R. Nunes ${ }^{1,2,3, *(\mathbb{D}) \text {, Margarida Casau }}{ }^{2}$ and Marta Ferreira Dias ${ }^{2,3}$ (D) \\ 1 PROMETHEUS, Unidade de Investigação em Materiais, Energia e Ambiente para a Sustentabilidade, Escola \\ Superior Agrária, Instituto Politécnico de Viana do Castelo, Rua da Escola Industrial e Comercial de \\ Nun'Alvares, 4900-347 Viana do Castelo, Portugal \\ 2 DEGEIT, Departamento de Economia, Gestão, Engenharia Industrial e Turismo, Universidade de Aveiro, \\ Campus Universitário de Santiago, 3810-193 Aveiro, Portugal; amcasau@ua.pt (M.C.); mfdias@ua.pt (M.F.D.) \\ 3 GOVCOPP, Unidade de Investigação em Governança, Competitividade e Políticas Públicas, Universidade de \\ Aveiro, Campus Universitário de Santiago, 3810-193 Aveiro, Portugal \\ * Correspondence: leonelnunes@esa.ipvc.pt
}

Citation: Nunes, L.J.R.; Casau, M.; Ferreira Dias, M. Portuguese Wood Pellets Market: Organization, Production and Consumption Analysis. Resources 2021, 10, 130. https://doi.org/

$10.3390 /$ resources 10120130

Academic Editor: Carlo Ingrao

Received: 19 October 2021

Accepted: 16 December 2021

Published: 20 December 2021

Publisher's Note: MDPI stays neutral with regard to jurisdictional claims in published maps and institutional affiliations.

Copyright: (c) 2021 by the authors. Licensee MDPI, Basel, Switzerland. This article is an open access article distributed under the terms and conditions of the Creative Commons Attribution (CC BY) license (https:// creativecommons.org/licenses/by/ $4.0 /)$.

\begin{abstract}
Wood pellets are a form of energy that can be seen as an alternative to fossil fuels, thus contributing to the reduction of greenhouse gas emissions. In other words, wood pellets can be considered a solution contributing to the mitigation of climate change. The use of wood pellets has grown significantly in recent years, with different markets emerging, such as Portugal, both from production and consumption perspectives. The wood pellet industry in Portugal began its development about 15 years ago, with the companies installed in the country initially almost exclusively dedicated to the production of wood pellets for export to central and northern European markets. However, over the years, the domestic market, initially considered insignificant, began to develop; it recently reached a considerable consuming share of the national production. This study presents an analysis of the Portuguese wood pellet market using data collected on the sector, and specifically on producers and consumers. The information was gathered using surveys presented directly to consumers and producers and through interviews with other stakeholders in the sector. From the analysis of the information, it was possible to understand the market's dynamics, its current evolution and its prospects for the upcoming years, since it can already be considered mature and consolidated.
\end{abstract}

Keywords: wood pellets; Portuguese market; biomass energy production; consumption habits; sustainability

\section{Introduction}

Renewable energies are currently playing a decisive role in fighting climate change, as their use replaces fossil fuels, and they have been presented as a high-potential alternative solution, specifically when using residual raw materials, for example, from forest management operations or agriculture activity [1]. In this way, the use of biomass to replace oil, coal or natural gas assumes a double advantage, since, besides the expected replacement of fossil fuels by carbon-neutral fuels, it also contributes to waste recovery, enhancing circular economy processes [2].

The promotion of biomass as an alternative energy source has been the subject of several works over the last years. This has somehow resumed the use of what is, without doubt, the oldest form of energy that humanity had access to, which was triggered by the discovery of fire [3]. Currently, biomass has a global generalized use, although this use is made in different ways depending on the type of users [4]. The use of biomass in developed countries is conducted from the perspective of replacing fossil fuels and decarbonizing the economy using technologically advanced processes. However, in less developed countries, the use of biomass occurs in a rudimentary way, using direct combustion processes to satisfy basic needs such as heating or cooking [5]. For this reason, biomass may be considered 
the "energy of the poorest", since its direct use allows the satisfaction of basic needs of the populations and is available in practically all latitudes at a low cost [6]. This was the argument underlying the widespread use of biomass even in developed countries, which, coupled with environmental arguments such as carbon neutrality as a way of mitigating climate change, contributed to increase the use of biomass-derived fuels [7]. Obviously, the impact is different when it comes to industrial consumption, such as in thermal power plants, than when it comes to domestic-scale consumption [8]. For domestic uses, which are within the reach of all citizens, allowing anyone to contribute to reduce greenhouse gas emissions, there is an adaptable set of technologies, namely, solar energy, for the production of electricity and hot water, or small aerogenerators, for the production of electricity [9]. However, in this domestic use, wood pellets are the most popular option, given the competitive advantages in terms of costs compared to other forms of energy used for heating and hot water production [10].

In fact, the domestic use of wood pellets reached an increasing dispersion. This, however, did not occur at the same time in all countries, with central and northern European countries taking the lead in their use, justified by the harsh winters felt in these regions [11]. Southern European countries, which saw the production of wood pellets as very promising from the perspective of exportation to northern markets, also started to develop their internal markets-first from an industrial use perspective, e.g., with the use of wood pellets and wood chips in the textile industry for steam production, but then quickly gaining consumers for the generation of domestic hot water and central heating [12,13].

This research aimed to characterize the wood pellet market in Portugal, which initially showed itself as a large producer and exporter, but quickly saw its internal market developing and prospering to the point that domestic use of wood pellets became common. To this end, a survey was carried out, shared through social networks such as Facebook and LinkedIn, to collect data that characterized consumption habits. Information and product samples available on the market were also collected throughout the five years. Information on wood pellet manufacturers was also collected through a survey to the producers to understand the evolution of commercial procedures in use. According to the data collected, this article presents analysis and characterization of the wood pellet market in Portugal.

\section{Materials and Methods}

\subsection{Framework}

The use of digital surveys allows interaction with many participants who may be in geographically different regions. Using these tools, such as Google Forms or Monkey Survey, it is possible to overcome the barriers of distance and even the need to make telephone contacts, as happened in the recent past. Online surveys in marketing research already have an extensive background, as highlighted by the work of Ilieva et al. (2002), in which the authors classified online surveys as a new kind of data collection rather than a new data-collection method [14]. On the other hand, Van Selm and Jankowski (2006) presented a comparative study on conducting online surveys using two types of electronic or online surveys available for data collection, the email and the web-based survey. This work addressed a multitude of issues that researchers should consider before and during the use of these methods of data collection [15]. Lafever et al. (2006) analyzed the advantages and disadvantages of online data collection in academic research [16]. In this work, the authors emphasized carrying out qualitative studies, using email to contact participants, and concluded that online surveys might reach larger populations and achieve quicker returns. Keusch (2015) presented a work that analyzed the reasons that lead people to participate in web surveys, applying survey participation theory to internet survey data collection. In this work, the author concluded that the concepts of self-perception, cognitive dissonance, commitment and involvement, social exchange, compliance, leverage salience and planned behavior were empirically proven to influence web participation [17], building upon the work of Mellis and Bickel (2020), in which the authors distributed surveys through the social network Facebook [18]. 
To carry out this study, information was collected through surveys of stakeholders in the sector, such as wood pellet manufacturers, distributors, and final consumers. In the present work, more preponderance was given to domestic users; small industrial consumers, such as bakeries, restaurants, etc.; and consumers of the hospitality industry, such as hotel units, retirement houses, municipal swimming pools, or similar institutions. The surveys were developed using Google Forms in the Portuguese language and made available through social and professional networks such as Facebook and LinkedIn, in the case of the survey to consumers, and through direct contact by email, in the case of producers. In any case, the link provided led to the survey form, which was archived after being filled out and submitted. The form submitted for the consultation of consumers was anonymous, as respondents were requested to fill in only their location and never any personal data that could in any way lead to the identification of the enquired. In the case of the survey sent to wood pellet producers, the survey link was sent via a message to the email addresses provided on the official web pages of the companies. Unlike that used for consumers, this survey asked for the name of the company and the brands marketed. However, it did not allow the identification of the person responsible for answering the survey. As a matter of brand and company name safety, this article does not use commercial references relating to any company or brand, and the data are treated generically, since the objective was to characterize the market, not a particular company or brand. The elaboration of the survey followed the guidelines presented by Dillman (2011) concerning the preparation of a tailor-made survey, in which respondents quickly answer a set of questions without being asked about personal issues, since many sometimes feel embarrassed about providing this type of information [19].

\subsection{Collection of Information and Sampling Products Available on the Market}

To characterize the products, samples of all brands marketed in Portugal were collected. These brands are available to users in $15 \mathrm{~kg}$ bags, all from national producers or distributors. Brands produced outside the country, namely some brands from Spain that were for sale in Portugal, mainly in borderline regions, were excluded from this inventory. This sample collection was carried out through the acquisition of $15 \mathrm{~kg}$ bags in superand hypermarkets and building material stores, all belonging to large international chains with representation throughout the national territory, and in stores belonging to national companies with more local and regional representation, fuel stations, companies selling combustion equipment, agricultural cooperatives and local distributors. This sampling was carried out between October 2014 and December 2020.

\subsection{Survey Conducted with Consumers}

The survey conducted with consumers had as its main objective to assess the current state of knowledge that the Portuguese people have about the wood pellet sector and the current state of wood pellet use. The survey was carried out using Google Forms, and the link subsequently generated (https:/ / forms.gle/E5ySXtjkLnsJrPUWA) was posted in social networks such as Facebook and LinkedIn. The target population covered by the two social networks, estimated for Portugal, was around 6 million users, for a degree of confidence of $95 \%$, which allowed calculating a margin of error of $3 \%$ for the survey carried out. The conduction of this survey complied with the legal requirements provided in Law no. 58/2019, of 8 August, which ensures the implementation, in the national legal order, of Regulation (EU) 2016/679 of the Parliament and the European Council, of 27 April 2016, on the protection of individuals regarding the processing of personal data and the free movement of such data.

The survey, carried out in Portuguese, consisted of several questions, some of which were eliminatory regarding the knowledge that citizens had on the subject, specifically on whether they knew about the existence of wood pellets and, if so, what use they gave them. The location of the respondents was also requested to obtain information of a regional nature on the knowledge about the subject and be able to create a national 
consumption map. Thus, the survey was divided into five different sections as shown in the following tables.

The first section, which is presented in Table 1, presents the survey, its purpose, the title "Market Study: The Use of Wood Pellets in Portugal" and a brief introductory note in which it was stated that this study aimed to analyze the use of wood pellets and assess the degree of knowledge of consumers about the products available on the market. This introductory note also referred to the confidentiality of the data provided and their educational use. In this section, all answers were mandatory, as they were fundamental for contextualizing the data collected. For example, indicating the location where the survey was answered made it possible to verify the differences among regions, and answering the question "Have you ever heard of wood pellets?" made it possible to eliminate participants who could not bring factual data to the survey, thereby allowing analysis of the state of maturity of a product that was available at least since 2007 . Respondents who positively validated this answer moved on to the next question, "Do you use wood pellets?". Those who responded negatively ended their participation, since the following questions were related to their use.

Table 1. Set of initial questions regarding the knowledge about wood pellets.

\begin{tabular}{cclc}
\hline & Questions & \multicolumn{2}{c}{ Possible Answers } \\
\hline 1. & Location & 1.1. & Answer in full \\
2. & Ever heard of wood pellets? & 2.1. & Yes \\
& & 2.2. & No \\
3. & Do you use wood pellets? & 3.1. & Yes \\
& & 3.2. & No \\
\hline
\end{tabular}

The section presented in Table 2 collected information on the use given to wood pellets by consumers, such as size and preferred acquisition format, as well as data on the market, namely the preferred purchase location, date of first use, quantity purchased annually, quantity purchased each time, price of first purchase, price of current purchases and if these prices included delivery to the place of use.

Table 2. Set of questions regarding the types of use that consumers gave to wood pellets.

\begin{tabular}{|c|c|c|c|}
\hline & Questions & & Possible Answers \\
\hline \multirow{3}{*}{4.} & \multirow{3}{*}{$\begin{array}{l}\text { What kind of use do you give to wood } \\
\text { pellets? }\end{array}$} & 4.1. & $\begin{array}{l}\text { Domestic use for heating and /or hot } \\
\text { water production? }(<50 \mathrm{~kW})\end{array}$ \\
\hline & & & Semi-industrial use for heating \\
\hline & & 4.2 . & $\begin{array}{l}\text { and/or hot water production? } \\
(50 \mathrm{~kW}-300 \mathrm{~kW})\end{array}$ \\
\hline \multirow{7}{*}{5.} & \multirow{7}{*}{ For what purpose do you use wood pellets? } & 4.3 . & $\begin{array}{l}\text { Industrial use for heating and/or hot } \\
\text { water and/or steam production? } \\
\qquad(>300 \mathrm{~kW})\end{array}$ \\
\hline & & 5.1. & Ambient space heating \\
\hline & & 5.2. & Domestic hot water \\
\hline & & 5.3. & Heating and domestic hot water \\
\hline & & 5.4 . & $\begin{array}{l}\text { Hot air generation (e.g., in aviaries or } \\
\text { greenhouses) }\end{array}$ \\
\hline & & 5.5 . & $\begin{array}{l}\text { Industrial steam generation (using } \\
\text { steam boilers or steam generators) }\end{array}$ \\
\hline & & 5.6. & $\begin{array}{c}\text { Industrial ovens (for example, in } \\
\text { bakeries or } \\
\text { ceramic industry, among others) }\end{array}$ \\
\hline \multirow{5}{*}{6.} & \multirow{5}{*}{ How do you buy wood pellets? } & 6.1 . & $15 \mathrm{~kg}$ bag \\
\hline & & 6.2. & $15 \mathrm{~kg}$ bag pallet (approximately 1 ton) \\
\hline & & 6.3. & $500 \mathrm{~kg}$ big bag \\
\hline & & 6.4 . & $1000 \mathrm{~kg}$ big bag \\
\hline & & 6.5 . & Bulk \\
\hline
\end{tabular}


Table 2. Cont.

\begin{tabular}{|c|c|c|c|}
\hline \multicolumn{2}{|r|}{ Questions } & \multicolumn{2}{|r|}{ Possible Answers } \\
\hline 7. & $\begin{array}{l}\text { How much do you consume } \\
\text { annually? (in } \mathrm{kg} \text { ) }\end{array}$ & 7.1. & Answer in full \\
\hline 8. & How much do you buy at a time? (in kg) & $\begin{array}{l}8.1 . \\
9.1 .\end{array}$ & $\begin{array}{l}\text { Answer in full } \\
\text { Supermarkets }\end{array}$ \\
\hline 9. & Where do you usually buy wood pellets? & $\begin{array}{l}9.2 . \\
9.3 . \\
9.4 .\end{array}$ & $\begin{array}{l}\text { Distributors } \\
\text { Equipment Installers } \\
\text { Producers }\end{array}$ \\
\hline 10. & $\begin{array}{c}\text { Since when have you used wood } \\
\text { pellets? (years) }\end{array}$ & 10.1. & Answer in full \\
\hline 11. & $\begin{array}{c}\text { Do you remember the price of wood pellets } \\
\text { when you first bought them? (VAT } \\
\text { included) }\end{array}$ & 11.1. & Answer in full \\
\hline 12. & $\begin{array}{c}\text { What was the price of wood } \\
\text { pellets the last time you bought them? (VAT } \\
\text { included) }\end{array}$ & 12.1. & Answer in full \\
\hline 13. & $\begin{array}{c}\text { Does the amount you pay include delivery } \\
\text { of the wood pellets at home? }\end{array}$ & $\begin{array}{l}13.1 . \\
13.2 .\end{array}$ & $\begin{array}{l}\text { Yes } \\
\text { No }\end{array}$ \\
\hline
\end{tabular}

The information collected in Table 2 referred to the types of use consumers gave to wood pellets, namely domestic, semi-industrial or industrial use. This classification is defined by the installed thermal power capacity, where usually domestic applications use equipment with thermal power capacity of less than $50 \mathrm{~kW}$, semi-industrial applications use equipment with thermal power capacity between $50 \mathrm{~kW}$ and $300 \mathrm{~kW}$ and industrial type applications use equipment with thermal power capacity greater than $300 \mathrm{~kW}$. However, it was clarified that the designation used, specifically for the industrial type, did not necessarily refer to industrial units but instead to installed equipment, for example, in public service buildings, such as municipal swimming pools, retirement houses, or similar, where energy needs imply considerable consumption of fuel. This set of questions also collected data about the destination of the energy produced, allowing, together with the previous question, understanding the type of use the energy produced was intended for. The following questions addressed the acquisition process through the collection of information about the quantities purchased, the frequency of purchases and when consumers used the product. The data regarding acquisition prices ended this section of the questionnaire. These constituted a set of essential information for establishing the practiced prices in the national market.

In the next section, which is presented in Table 3 , information about the market was collected, namely about the fuel that consumers used before starting to use wood pellets and if they had an idea of the savings achieved if they previously used another fuel source for the same purpose. Information was also collected regarding the most important criteria to consider when purchasing wood pellets and whether it was relevant to the consumer that the pellets purchased had an ENPlus ${ }^{\circledR}$ certificate.

The information collected through the responses obtained in this section allowed us to assess which fuels were most used in the period prior to the appearance of wood pellets. These answers also gave information regarding the savings obtained from replacing fuels and the main criteria for purchasing a specific wood pellet brand instead of another. Finally, information about preference for white brands or recognized brands was also obtained, since both products are commercialized in the entire country. 
Table 3. Set of questions referring to the fuels used, the savings achieved with the replacement of previous fuels and the criteria for choosing the products purchased.

\begin{tabular}{|c|c|c|c|}
\hline & Questions & & Possible Answers \\
\hline 14. & $\begin{array}{l}\text { What fuel did you use before wood } \\
\text { pellets? }\end{array}$ & $\begin{array}{l}14.1 . \\
14.2 . \\
14.3 . \\
14.4 . \\
14.5 . \\
14.6 .\end{array}$ & $\begin{array}{c}\text { None } \\
\text { Diesel } \\
\text { Natural gas } \\
\text { Propane gas } \\
\text { Firewood } \\
\text { Other }\end{array}$ \\
\hline 15. & $\begin{array}{l}\text { If you answered "Other" in the } \\
\text { previous question, may you } \\
\text { indicate which fuel you used } \\
\text { before the wood pellets? }\end{array}$ & 15.1. & Answer in full \\
\hline 16. & $\begin{array}{l}\text { Do you have any idea of the } \\
\text { savings achieved in relation to the } \\
\text { previous fuel? } \\
\text { (approximate \%) }\end{array}$ & 16.1. & Answer in full \\
\hline 17. & $\begin{array}{l}\text { What are your main criteria for buying } \\
\text { wood pellets? }\end{array}$ & $\begin{array}{l}17.1 \\
17.2 . \\
17.3 . \\
17.4 . \\
17.5 .\end{array}$ & $\begin{array}{l}\text { Price } \\
\text { Quality of the product } \\
\text { Certification of the product } \\
\text { Proximity to the supplier } \\
\text { None of the above }\end{array}$ \\
\hline 18. & $\begin{array}{l}\text { If you answered "None of the above" } \\
\text { in the previous question, may you } \\
\text { indicate which criteria you do use? }\end{array}$ & 18.1. & Answer in full \\
\hline 19. & Do you prefer any brand? & $\begin{array}{l}19.1 \\
19.2\end{array}$ & $\begin{array}{l}\text { Yes } \\
\text { No }\end{array}$ \\
\hline
\end{tabular}

In the last section of the questionnaire, shown in Table 4, information was collected on how consumers purchased wood pellets and which product quality criteria were most important at the time of decision making.

Table 4. Questions regarding the quality of products and its impact on the purchase decision.

\begin{tabular}{|c|c|c|c|}
\hline \multicolumn{2}{|r|}{ Questions } & \multicolumn{2}{|c|}{ Possible Answers } \\
\hline 20. & $\begin{array}{l}\text { Choose the most important } \\
\text { property when selecting the product. }\end{array}$ & $\begin{array}{l}20.1 . \\
20.2 \\
20.3 \\
20.4\end{array}$ & $\begin{array}{c}\text { Ash content } \\
\text { Chlorine content } \\
\text { Heating value } \\
\text { None of the previous }\end{array}$ \\
\hline 21. & $\begin{array}{l}\text { If you answered "None of the above", } \\
\text { may you indicate which properties are } \\
\text { important? }\end{array}$ & 21.1. & Answer in full \\
\hline 22. & $\begin{array}{l}\text { When you have to choose a brand of } \\
\text { pellets that you don't know, what is } \\
\text { the most important negative } \\
\text { characteristic for you? }\end{array}$ & $\begin{array}{l}22.1 . \\
22.2 . \\
22.3 . \\
22.4\end{array}$ & $\begin{array}{l}\text { Dust in the bag } \\
\text { Pellet size } \\
\text { Pellet color } \\
\text { None of the above }\end{array}$ \\
\hline 23. & $\begin{array}{l}\text { If you answered "None of the above", } \\
\text { may you indicate which negative } \\
\text { characteristics are important for you? }\end{array}$ & 23.1. & Answer in full \\
\hline 24. & Do you prefer certified pellets? & $\begin{array}{l}24.1 \\
24.2\end{array}$ & $\begin{array}{l}\text { Yes } \\
\text { No }\end{array}$ \\
\hline
\end{tabular}

In this set of questions, consumers indicated which properties were most important when purchasing wood pellets based on quality parameters with limit values defined by the ENPlus ${ }^{\circledR}$ certification standard. Thus, parameters such as ash content, chlorine content and heating value were presented as the most easily identifiable aspects for consumers. 


\subsection{Survey for Wood Pellets Manufacturers and Distributors}

The survey distributed to producers and large distributors of wood pellets was carried out following the same assumptions used in the survey of consumers. The survey showed conceptual differences, since the anonymity of the participants was not maintained, and the names of the companies for which they responded was asked. In addition to distributing the survey through the social network LinkedIn, a message was also sent by email to all the companies. This identification tried to be as comprehensive as possible, including some companies that have closed between the time of contact and the time of publication. Thus, in addition to the identification of companies, which are not disclosed during this study, their locations were highlighted, followed by a set of other questions, as shown in Table 5 .

Table 5. Questions used in the survey made available to producers and large distributors of wood pellets.

\begin{tabular}{|c|c|c|c|}
\hline \multicolumn{2}{|r|}{ Questions } & \multicolumn{2}{|r|}{ Possible Answers } \\
\hline 1. & Company name & & Answer in full \\
\hline 2. & Location (municipality) & & Answer in full \\
\hline \multirow{2}{*}{3.} & Do you have your own & 3.1. & Yes \\
\hline & production? & 3.2. & No \\
\hline \multirow{2}{*}{4.} & \multirow{2}{*}{ Do you use your own brand? } & 4.1. & Yes \\
\hline & & 4.2. & No \\
\hline \multirow[t]{2}{*}{5.} & What brand do you use in the marketing of pellets? & 5.1. & Answer in full \\
\hline & Annual production capacity (in the case of producers) & & \\
\hline 6. & $\begin{array}{l}\text { or annual sales capacity (in the case of } \\
\text { distributors) (t/year)? }\end{array}$ & 6.1. & Answer in full \\
\hline 7. & $\begin{array}{c}\text { In what year did you start activity (with } \\
\text { effective production)? }\end{array}$ & 7.1. & Answer in full \\
\hline 8. & What raw materials do you use in production? & 8.1. & Answer in full \\
\hline 9. & Are you ENplus certified? & 9.1. & $\begin{array}{l}\text { Yes } \\
\text { No }\end{array}$ \\
\hline \multirow{2}{*}{10.} & Do you have any other & 10.1. & Yes \\
\hline & certifications? (quality, HSW, environment, RDI, etc.) & 10.2 & No \\
\hline 11. & $\begin{array}{l}\text { If yes in the previous question, may you indicate } \\
\text { which ones? }\end{array}$ & 11.1. & Answer in full \\
\hline \multirow{4}{*}{12.} & What kind of pellets do you & 12.1. & Industrial \\
\hline & produce? & 12.2 & Domestic \\
\hline & & 13.1. & $10 \mathrm{~kg}$ bags \\
\hline & & 13.2. & $15 \mathrm{~kg}$ bags \\
\hline \multirow{4}{*}{13.} & In what formats do you sell & 13.3. & $500 \mathrm{~kg}$ big bags \\
\hline & pellets? & 13.4. & $1000 \mathrm{~kg}$ big bags \\
\hline & & 13.5. & $1250 \mathrm{~kg}$ big bags \\
\hline & & 13.6. & Bulk \\
\hline \multirow{2}{*}{14.} & \multirow{2}{*}{ Does your company export? } & 14.1. & Yes \\
\hline & & 14.2 & No \\
\hline \multirow[t]{2}{*}{15.} & $\begin{array}{l}\text { What percentage of your } \\
\text { production goes to export? }\end{array}$ & 15.1 & Answer in full \\
\hline & & 16.1. & $\begin{array}{l}\text { United Kingdom (England, Scotland, } \\
\text { Ireland and Wales) }\end{array}$ \\
\hline \multirow{6}{*}{16.} & Which are the most important countries you export & 16.2. & $\begin{array}{c}\text { Spain (includes Andorra and } \\
\text { Gibraltar) }\end{array}$ \\
\hline & to? & 16.3. & France \\
\hline & & 16.4. & Italy \\
\hline & & 16.5 & Netherlands, Belgium, Luxembourg \\
\hline & & 16.6 & $\begin{array}{l}\text { Scandinavia (Sweden, Norway, } \\
\text { Denmark and Finland) }\end{array}$ \\
\hline & & 16.7. & $\begin{array}{l}\text { Central Europe (Germany, } \\
\text { Switzerland, Austria and France) }\end{array}$ \\
\hline 17. & $\begin{array}{c}\text { May you indicate the average sale price of pellets in } \\
\text { 2016, 2017, } 2018 \text { and 2019? (EUR/ton or } \\
\text { EUR/bag_-rices excluding VAT) }\end{array}$ & 17.1. & Answer in full \\
\hline
\end{tabular}

This questionnaire was intended to obtain market information from the perspective of producers and distributors, allowing, through the analysis of these results and the results obtained in the questionnaire carried out to consumers, comparison of the responses presented on both sides, particularly regarding pricing. 


\section{Literature Review}

Currently, the existing markets for wood pellets are at different development stages, since their implementation took place in different periods. Though palletization as a wood densification technique is already quite old (see the work of Swictochowski et al. (1815), in which the authors characterized the properties of wood pellets produced with mixtures of wood and cereal straw, and the work of Maliga and Patil (1824), in which the authors already address aspects related to the combustion of different types of biomass and compared this combustion with that of natural gas), its widespread use has only been seen in more recent periods [20,21]. The work by Ahn et al. (1980) already presented an assessment of biomass resources from the market perspective, and the work of Hathaway et al. (1980) addressed the topic of densified biomass use from the perspective of large-scale use in thermal power plants $[22,23]$.

In the 1990s, specific works on the characterization of national markets were frequent. In the case of the United States of America, studies were conducted at the state level, given the size and territorial organization of the United States. Examples can be found in the works by Haase (1993), which analyzed the production of wood pellets in the North American state of Colorado; by Bentzen et al. (1996), which analyzed the availability and competitiveness of the Danish market from the perspective of sustainable energy supply to rural regions; by Aruna et al. (1997), which presented as a case study the Swedish market and its export capacity; or by Hillring and Vinterback (1998) on the Swedish market, in which characterization of the residential market was presented as well. Hillring (1999) presented an analysis of the markets in Sweden and the evolution of prices from a regional perspective and in other work presented a national perspective [24-29]. Hughes (1999) presented an analysis of equipment available in the North American market, while Roos et al. (1999) analyzed the critical factors for the implementation of bioenergy use models, including models for wood pellets [30,31]. The use of wood pellets, although not exclusive to the United States of America and Northern Europe, is still in a phase of affirmation and development in these countries, which may be considered pioneers.

In the 2000s, the studies continued on pioneering markets such as Sweden, with the characterization of the use of wood pellets by the residential sector by Vinterbäck (2000) [32]. However, the first works on new markets also appeared, such as that presented by Cotton and Giffard (2001), which addressed the introduction of bioenergy pellets as fuel in the United Kingdom; that presented by Alakangas and Paju (2002), which was on the use of wood pellets in Finland; that presented by Medlener and Gustavsson (2003), which characterized the use of small-scale heating systems for wood pellets in Austria; or that presented by Kaygusuz and Türker (2002), which evaluated the energy potential of biomass in Turkey [33-36]. Also from this period were the first comparative studies between fuels that included wood pellets for district heating units, such as that carried out by Mölder (2003) in the Jogeva district in Estonia, as well as the first reference to the Italian market, presented by Bartolelli et al. (2002) in a report on the status of bioenergy use in different European countries $[37,38]$. Aleksandrova (2008) analyzed how the biomass pellet market was created in Russia, thus demonstrating that the use of this biomass-derived fuel had already left its initial frontiers and was rapidly becoming the subject of research and technical and economic analysis [39]. Further in this vein, Wang and Yan (2003) had already presented a feasibility study on the production and use of wood pellets to replace coal in China [40]. Also in Asia, Yagi and Nakata (2006) started economic evaluation as a political option for the use of wood pellets as fuel in Japan [41]. Tarasov (2009) presented the first market study for Russia, and Rakitova et al. (2009) analyzed the production and marketing of wood pellets in Russia, Belarus and Ukraine. Wood pellet use also advanced to Poland, according to an analysis by Mikołajazak (2009) [42-44]. Furthermore, from an early date, the southern regions of Europe were the object of study, mainly because of the capacity of these regions to produce large quantities of biomass, which allows them to serve as producing and exporting regions for markets where higher consumption would be expected. Thus, Pigaht et al. (2004) presented a study addressing the production of 
wood pellets in southern Europe from the perspective of characterization of resources, new products and new markets, while Passalacqua and Zaetta (2004) studied, in the same region, the production of pellets from residual agricultural biomass as a way of valorizing endogenous resources $[45,46]$.

In the decade 2010-2020, studies intensified, no longer dealing exclusively with market analysis, descriptive approaches and presenting each country as a case study, but rather integrating views and analyses, for example, using life cycle analysis models, such as in the work presented by Laschi et al. (2016); analysis of supply chains, as in the work presented by Smith and Junginger (2011); analysis of greenhouse gases emissions, as in the work presented by Sjølie and Solberg (2011); or even the cofiring of wood pellets with charcoal, as the work presented by Xian et al. (2015) [47-50]. In the case of Portugal, although biomass as an energy source is a traditional practice and common to all regions of the country, wood pellet use and production started only in mid-2005, most likely through the evolution of industrial units. These units produced biomass briquettes using residues from the wood flooring and furniture production industries but quickly evolved to constructing large production units with a capacities of more than 100,000 tons per year starting in 2006. The first feasibility study for the production of wood pellets in Portugal was conducted by Monteiro et al. (2013) and followed a previous study in which the same authors analyzed the Portuguese market for wood pellets from the perspective of production capacity and production constraints [51,52]. However, many different works on the subject originated in diverse latitudes. Nunes et al. (2014) presented a comparative study on the production of wood pellets in Portugal, Germany and Sweden, and Nunes et al. (2016) presented work on wood pellets as a sustainable energy alternative for Portugal [53,54].

\section{Results and Discussion}

\subsection{Products Available in the Domestic Market}

Over five years, pellets of all significant brands identified as having national origin were acquired in different types of commercial areas, such as super- and hypermarkets, fuel stations, wood pellet distributors, agriculture cooperatives, drugstores, thermal equipment stores, building material stores and installers of central heating and domestic hot water production equipment. At the time of purchase, the trademarks and purchase prices were registered. Figure 1 shows the trademarks acquired during the referred period and several others advertised on the internet.

Of all the identified brands, it was not possible to purchase any sample of pellets from the company/brand Ocean Pellets. After some contact attempts, the information was obtained that the company had not started operating yet, so it was assumed that the products advertised should be an exploratory model. During the sample collection period, whenever possible, new samples were acquired, even from previously collected brands. With this procedure, the study tried to confirm changes in the distributors' prices and verify the continuity of the brands over time. However, it was found that some of the brands shown in Figure 1 proved to be short-lived, and it was not possible to find them for sale in the following years. It was assumed that in some situations, such as that of the brand Nicepellets, the company ended its activity, while in others, such as that of SRN, which even supplied several large commercial stores in 2017, the companies were only trading companies and were not involved in production. In other words, they purchased wood pellets manufactured by other companies, which were later packaged under their brands. However, it is possible to identify in Figure 1 brands associated with some of the largest national producers, such as the brand Rubro, produced by Enerpellets, but also others in which the brand corresponds to the name of the company, such as Power Pellets, Pinewells, Stellep, Palser and Tecpellets. It is also possible to identify smaller producers, such as Martos (Omnipellets), Vimasol, BioMad and Biodense. As mentioned above, there is a wide range of distributors and independent packers that buy and sell wood pellets, including those that may be manufactured outside the national territory, namely in Spain. Some Spanish brands were also identified, mainly near the border areas. They were usually 
sold in small commercial stores, such as drugstores and building materials stores. A French brand of wood pellets was found in a gas station network. However, given their small impact on the market and the higher prices charged for them, it was decided to ignore their presence.
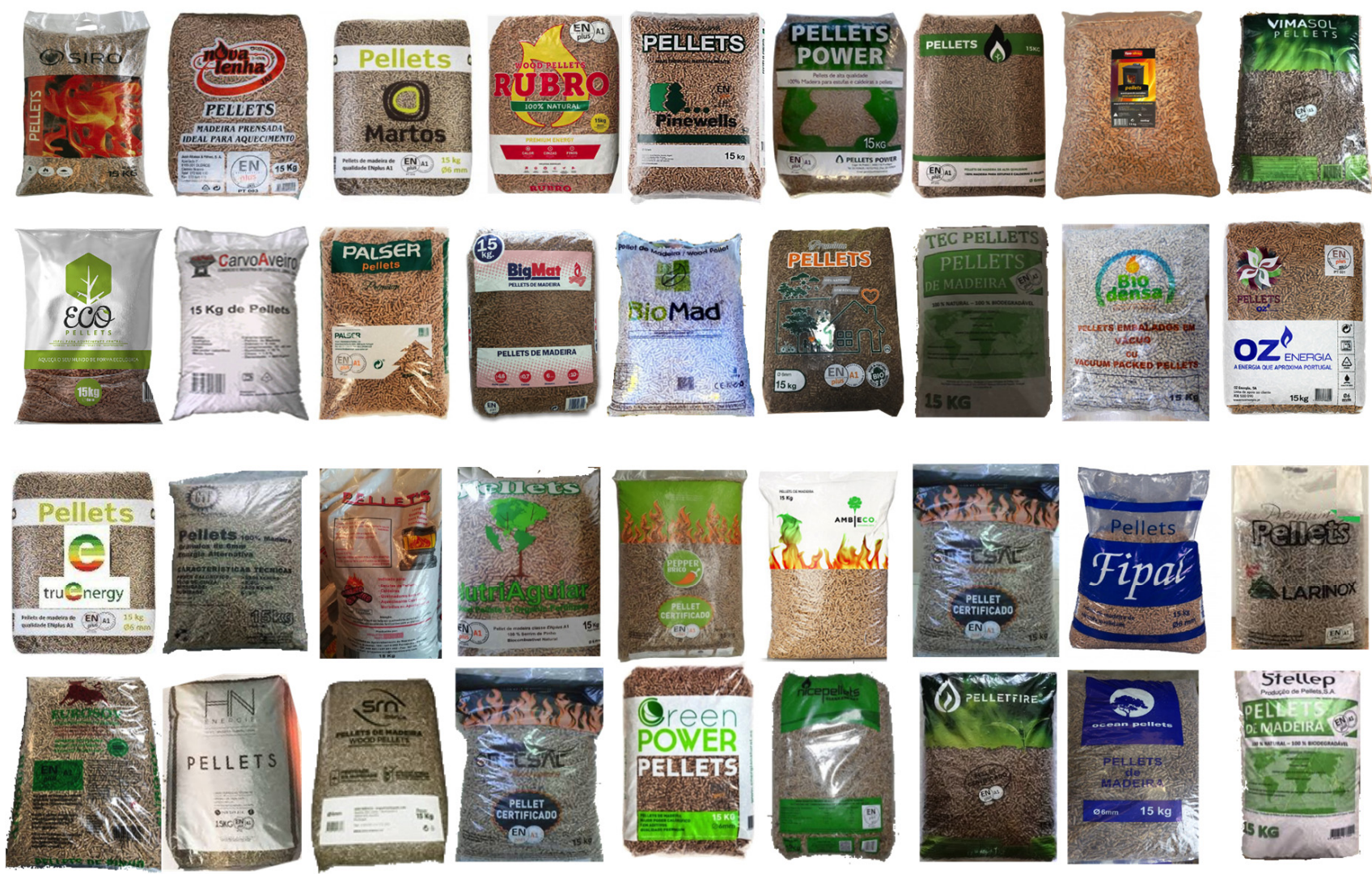

Figure 1. National wood pellets brands identified and advertised on the internet as being on sale between March 2015 and December 2020.

Figure 2 shows the distribution of sale prices to the public (including VAT) of purchased wood pellets.

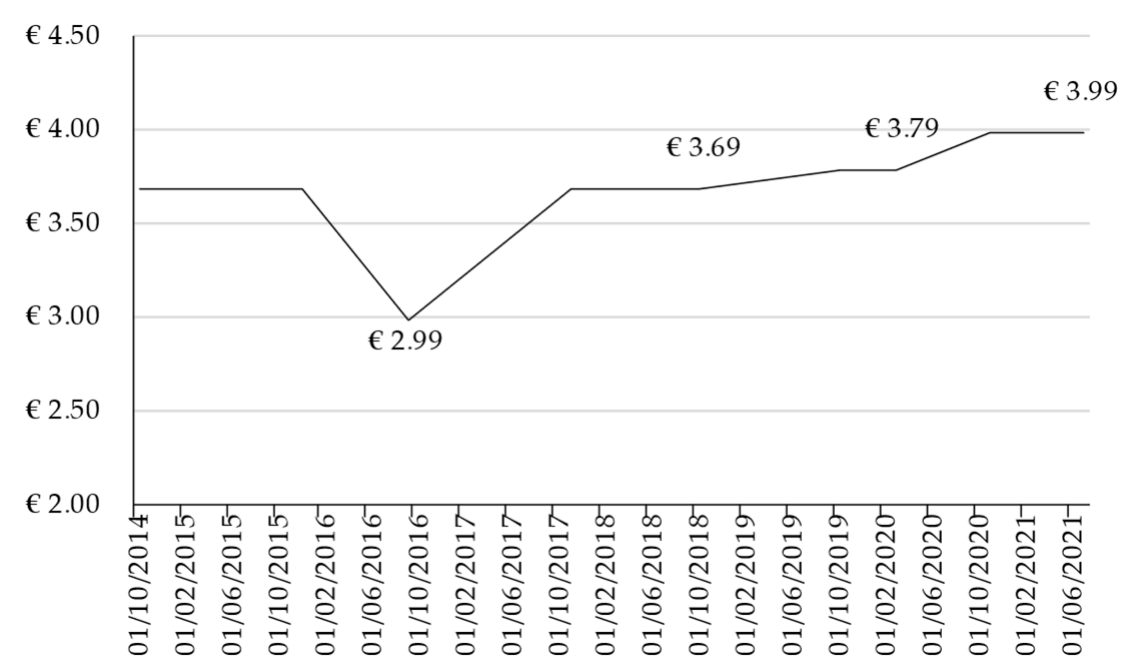

Figure 2. Distribution of sale prices to the public for $15 \mathrm{~kg}$ bags of wood pellets purchased between October 2014 and July 2021. 
As seen in Figure 2, a slight price increase is visible, which was probably related to the increases seen in the price of wood verified from 2017. However, the price quickly returned to its initial values, with the justification of an alleged lack of raw material caused by the incapacity (or lack of desire) of forest operators to fulfill the requests for supply. This justification seemed to be supported by a certain cartelization of the forestry sector rather than a valid argument, but it somehow justified this trend of rising prices for wood pellets, which was verified. The increase in energy cost could also be pointed to as a reason for this trend, or the reason could even have been a mix of the two possibilities presented.

Portugal has a significant number of companies with ENPlus ${ }^{\circledR}$ certification for their products. There are 22 certificates issued, although only 18 are active, with three certificates presented as being extinct on the website https: / enplus-pellets.eu/pt/certificacoes-pt-pt/ produtor-pt-pt.html. Regarding the quality of pellets produced in Portugal, the apparent quality observed (specifically what may be assessed through visual observation of the bagged product, for example, by the smell, color, fine content in the bag, density and dimensions of the pellets, or by the detection of residues (paper, textiles, plastics ... ) in the structure of the wood pellets) indicated that it was generally reasonable. The existence of many producers that had ENPlus ${ }^{\circledR}$ certificates was a signal of a desire to present a high-quality product. However, some (few) cases of improper use of certification were also detected. In the specific cases identified, the bags sold did not present a forgery of the certification logotype but presented the inscription "Wood pellets produced under the requirements of the ENPlus ${ }^{\circledR}$ brand", giving the idea of a probable certification. However, despite these isolated cases, Portuguese producers seemed to have a good reputation both nationally and internationally. No Portuguese company was found on the blacklist of the certifying entity, where producers from countries such as Poland, Ukraine, Russia, Romania, Italy, Spain and the United Kingdom abound. References to manufacturers from China, Brazil, Thailand and Cameroon also are listed. In this way, Portuguese producers present a recognized quality product that, together with the installed production capacity, places Portugal as one of the leading European exporters.

\subsection{Characterization of Wood Pellet Consumption}

In the survey, 2205 responses were obtained from all districts of mainland Portugal, distributed as shown in Table 6. We highlight the participation of Porto, with $26 \%$ of the total valid responses, and the district of Évora, with 13\%. Lisbon contributed $4 \%$. The districts of the Minho region, Viana do Castelo and Braga, contributed with 5\% and $7 \%$, respectively. The districts Vila Real and Bragança contributed with $1 \%$ each, and the districts in the interior of the central region, Viseu, Guarda and Castelo Branco, contributed with $5 \%, 2 \%$ and $1 \%$, respectively. It was expected that the interior districts of the country would show greater interest in the subject, since they had the harshest winters, but this did not turn out to be the case. On the contrary, the coastal districts, such as Aveiro, Coimbra, Leiria and Santarém, contributed with engaging participation, with 3\%, 3\%, $9 \%$ and $4 \%$ of the total valid answers, respectively. This was in line with the participation verified in the regions of Alentejo and Algarve, with the Portalegre, Setúbal, Beja and Faro districts representing 2\%, 9\%, 2\% and 3\% of the total valid responses, respectively. Évora reached $12 \%$, as mentioned before. This distribution of shares, which was considered representative, is in line with what was found in other studies in which shares were more representative in coastal districts, where there is greater access to information technology. The participation of Alentejo districts may be justified by the large university population, which usually collaborates in this type of survey [55].

The participants were asked about their geographic locations and subsequently if they had ever heard of wood pellets, which was an eliminatory question to continue answering the survey. Thus, out of a total of 2205 responses considered valid, $61 \%$ answered affirmatively, while $39 \%$ answered no, ending their participation in the survey. Thus, from the results obtained, it seemed that a significant number of respondents already knew the product. This showed an evolution of the market, as it did not happen a few 
years ago, when most of the time, consumers associated wood pellets with other types of uses, confusing them with animal feed or other similar products. It is common to see consumers purchasing wood pellets in large commercial areas, and consumers were already knowledgeable about its use in domestic and industrial applications.

Table 6. Distribution of responses by district of mainland Portugal.

\begin{tabular}{cc}
\hline Districts & Answers (\%) \\
\hline Viana do Castelo & 5 \\
Braga & 7 \\
Porto & 26 \\
Vila Real & 1 \\
Bragança & 1 \\
Aveiro & 3 \\
Viseu & 5 \\
Coimbra & 3 \\
Guarda & 2 \\
Leiria & 9 \\
Castelo Branco & 1 \\
Santarém & 4 \\
Lisbon & 4 \\
Portalegre & 2 \\
Setúbal & 9 \\
Évora & 12 \\
Beja & 2 \\
Faro & 3 \\
\hline
\end{tabular}

The group of respondents who answered affirmatively to the previous question were faced with whether, in addition to being aware, they also used wood pellets, to which $32.8 \%$ replied that they did use it, while $67.2 \%$ answered that they did not. Since this was also an eliminatory question, the participants who answered negatively ended their collaboration here, while the rest continued to the next section. As may be inferred from the data collected, a significant part of the participants who were aware of the product already used it. With this evidence, it may be stated that may be the main source of knowledge dissemination on the subject will most likely be the users themselves. In other words, a consumer satisfied with the change made from a previous fuel to wood pellets would inform a group of other people about the change, who in turn would replicate the example, disseminating the process.

The next section of questions included a set of more specific themes aimed at the consumers of wood pellets. In this case, the objective was to understand which type of uses for wood pellets was most frequent and how the energy conversion was done through the responses to two questions, as shown in Figure 3.

As can be seen in Figure 3, 95.2\% of the survey participants pointed to domestic use for heating and hot water production, using equipment with thermal power of less than $50 \mathrm{~kW}$, while $4.8 \%$ of the participants indicated that they used biomass pellets in a semiindustrial way for heating and hot water production, using equipment with thermal power between $50 \mathrm{~kW}$ and $300 \mathrm{~kW}$. This relationship indicated that the market preferentially consumed small-scale equipment in the forms of stoves for indoor heating spaces, most likely replacing traditional wood-burning fireplaces, and domestic hot water boilers and central heating. There seemed to be a substitution of preexisting diesel or propane gas boilers, which saw their prices rise in recent years, with users looking for more practical solutions from an economic point of view. When analyzing the answers obtained regarding the purpose of using wood pellets, $73.8 \%$ of respondents answered that they used them for heating, reinforcing the hypothesis that there was a predominance of stove-type equipment, while only $23.8 \%$ mentioned central heating and the production of domestic hot water as the preferred use. Again, this was in line with what was mentioned above. In Figure 3 it is also possible to observe that $2.4 \%$ of the respondents used wood pellets for the generation 
of hot air. However, since there has been a type of profile that mainly indicated a domestic use for wood pellets, the respondents probably considered that the generation of hot air was related to the use of stoves, so this percentage, with a high degree of certainty, could be added to the users of stoves. While in Portugal, the use of biomass hot-air generators is already frequent, particularly in aviaries, for heating the breeding pavilions, and in greenhouses, that did not seem to be the objective of the answers given because of the profile indicated by the respondents, as aforementioned.

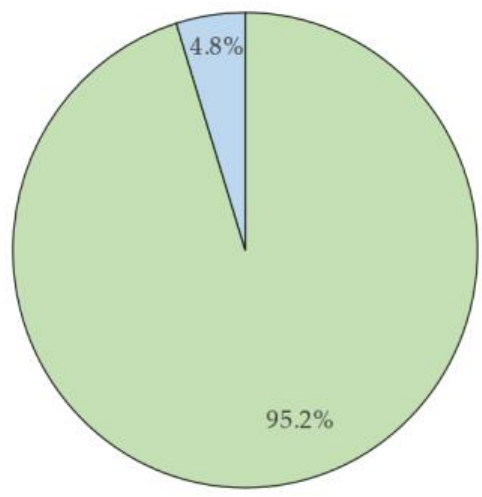

$\square$ Domestic use for heating and/or hot water production? $(<50 \mathrm{~kW})$

$\square$ Semi-industrial use for heating and/or hot water production? (50kW-300kW)

$\square$ Industrial use for heating and/or hot water and/or steam production? $(>300 \mathrm{~kW})$

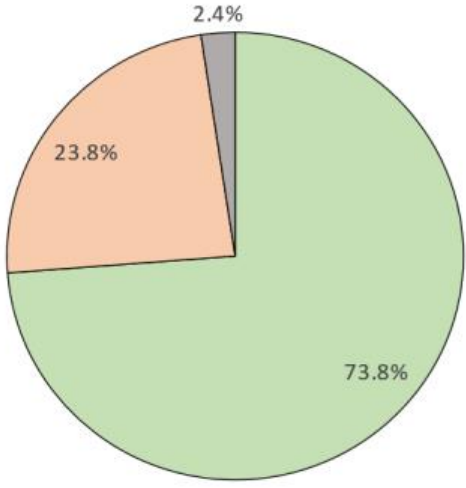

Ambient space heating

Domestic hot water

Heating and domestic hot water

$\square$ Generation of hot air (e.g., in aviaries or greenhouses)

$\square$ Industrial steam generation (using steam boile or steam generators)

Figure 3. Distribution of answers about the type of use and purpose of using wood pellets.

The answers obtained in the following question, shown in Figure 4, indicated that the dominant profile was the domestic user, as $73.8 \%$ responded that they bought wood pellets in the form of bags of $15 \mathrm{~kg}$. This type of consumption indicated acquisition in small quantities to satisfy current needs that, although regular, were not of a permanent type. In other words, this was a type of consumer who may be considered frequent but who did not maintain stocks of product and acquired fuel as they anticipated they needed it, ensuring their comfort, especially at times when they expects a more extended stay at home, for example, during weekends. On the other hand, a group with some expression also claimed that it acquired the same $15 \mathrm{~kg}$ bags, but in the form of a complete pallet, weighing approximately $1000 \mathrm{~kg}$. These consumers, who represented $19.1 \%$, showed a type of frequent intensive consumption probably related to the use of central heating boilers and domestic hot water production, being users who lived in houses with storage capacity. 


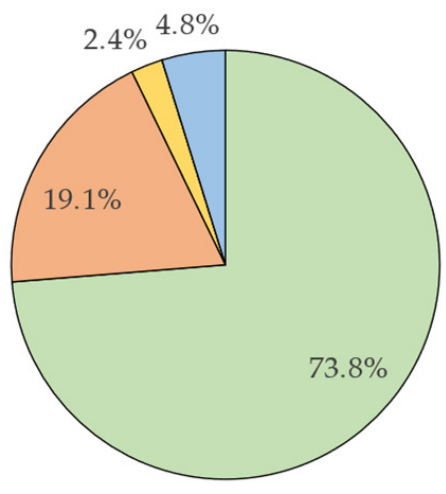

\author{
$\square 15 \mathrm{~kg}$ bags \\ $15 \mathrm{~kg}$ bag pallet (approximately 1 ton) \\ $\square 500 \mathrm{~kg}$ big bag \\ $1000 \mathrm{~kg}$ big bag
}

\title{
$\square$ Bulk
}

Figure 4. Distribution of answers about the acquisition format of wood pellets.

Regarding the acquisition format of wood pellets, $2.4 \%$ answered that they purchased wood pellets in $500 \mathrm{~kg}$ big bags, and $4.8 \%$ answered that they bought them in bulk. These respondents may be related to some more industrial uses. Although this was not mentioned in the answers on the type of use, they may be users who, although not using wood pellets for industrial purposes, had industrial-type structures such as forklifts and storage space. With these preconditions met, purchasing wood pellets in bulk formats would lead to benefits from more advantageous prices, resulting in savings compared to the fuels previously used.

The answer distribution observed for the question regarding the place of purchase of wood pellets confirmed the hypothesis presented in the previous paragraphs, since $61.9 \%$ of respondents indicated that they had supermarkets as their preferred place of purchase. This form of acquisition highlighted that most users had small equipment, usually of the salamander stove type, and bought small quantities at a time. Around $21.4 \%$ of users claimed that they bought wood pellets from distributors, most likely to receive quantity discounts. Likewise, another group representing $14.3 \%$ of the answers obtained indicated that they bought directly from manufacturers, also possibly to try to obtain a significant discount because they may buy in larger quantities. Another group, $2.4 \%$, claimed that they bought the wood pellets from the installers of the equipment they purchased. Most likely, these users replaced a preexisting boiler with one using another fuel or followed the recommendation of another user, with a promise from the equipment vendor to ensure both a permanent supply of wood pellets and maintenance and proper functioning of the equipment, thus countering possible breaches of the equipment warranty due to the use of uncertified fuels or doubtful quality. In this way, this misuse could never be blamed on the user, as the equipment installer would ensure the supply of fuels. Figure 5 shows the distribution of responses obtained regarding the location of acquisition of wood pellets.

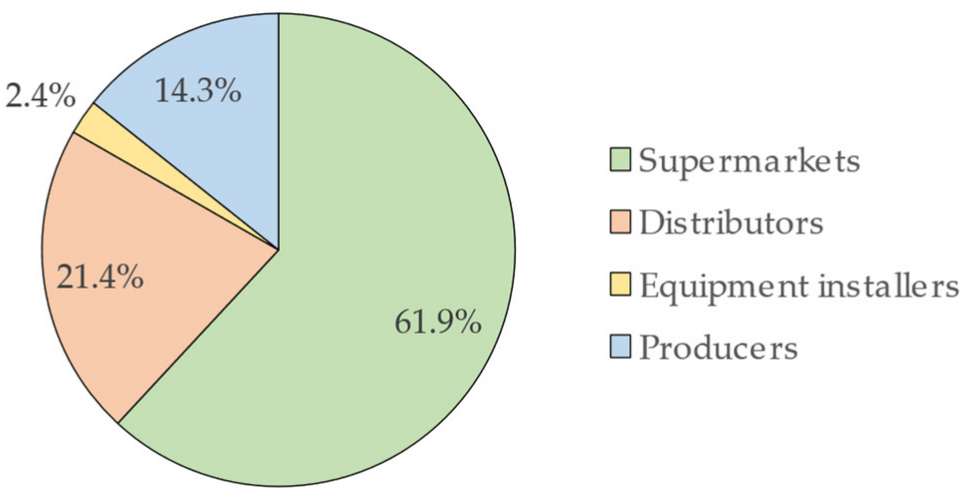

Figure 5. Distribution of answers regarding the purchase place of the wood pellets. 
The purchase of wood pellets directly from manufacturers, as mentioned by a significant group of consumers (14.3\%), was most likely by small production units with short ranges of action at the local or regional level or through knowledge of a personal/familiar nature, since usually, large production units do not sell outside the factory. These large units are more suited for selling large quantities, since they enter distribution channels such as supermarkets or other types of distributors. It is possible to make a direct relationship between the quantities consumed and the quantities purchased each time, since it seems logical that users who consume less tend to buy lower quantities at a time. On the other hand, consumers who spend more also tend to purchase larger quantities at a time and thus try to take advantage of the effects of economies of scale, for example, on price. One possibility that should be taken into consideration is that consumers who seek to purchase wood pellets outside the consumption season may benefit from even more significant discounts. However, this practice requires, in addition to the capital associated with storage costs, the availability of physical space for the storage itself. As can be seen from the responses, consumption is highly variable, with around $25 \%$ of respondents consuming less than $150 \mathrm{~kg} /$ year and another $25 \%$ consuming between 3000 and 12,000 kg/year. On the other hand, $50 \%$ of consumers distributed their consumption between 150 and $3000 \mathrm{~kg} /$ year, with the average value fixed in the range of 750 to $1250 \mathrm{~kg} /$ year. The amount purchased at a time had even more significant variability, as it varied from $15 \mathrm{~kg}$, for consumers who bought one bag at a time, to several tons, for consumers who bought in advance an amount they believed was sufficient for meeting all their yearly needs.

Regarding usage history, there was a growing trend of new users. There has been a significant increase in the number of users from that in 2015, although several users may be considered pioneers, as they claimed to have used wood pellets for over ten years; one of the participants even indicated that they had been using wood pellets since 2002. In this case, assuming that this was not an error in filling in the answer, this respondent may be a citizen now living in Portugal but may have first lived in another country in Central or Northern Europe, where the use of wood pellets was already a reality long before it arrived in Portugal.

Regarding the purchase price, which was presented with VAT included as the final sale price to the consumer, the values fluctuated in the range of 2.44 to 3.99 EUR per $15 \mathrm{~kg}$ bag, which indicated purchase in supermarkets as shown in Figure 6.

Regarding the last purchase price, most likely from the beginning of 2021, there was a trend towards higher average values than the prices indicated when purchasing wood pellets for the first time. It can be inferred that there was a trend towards an increase in the price of wood pellets, indeed associated with an increase in domestic demand. This issue also led producers to divert parts of production destined for export to domestic consumption, ensuring market stabilization. At the same time, they distributed resources so that consumers would bet on this new form of self-production of energy, as the cases of lack of supply, common in the initial years of implementation of the solution in Portugal, have been left behind. It is now possible to find wood pellets in supermarkets at any time of the year, not just in autumn and winter. The values presented in the survey ranged from 2.99 to 5 EUR per $15 \mathrm{~kg}$ bag, with the most frequent values between 3.15 and 3.99 EUR per $15 \mathrm{~kg}$ bag.

The distribution of responses obtained as to whether the amount paid for wood pellets included transport and delivery to the home showed that more than $\frac{3}{4}$ of the respondents, precisely $76.2 \%$, answered that transport was not included in the final purchase price of wood pellets, indicating that consumers went to the place of purchase, as with any other product available, for example, in supermarkets. The $23.8 \%$ who indicated that transport was included in the final purchase price were in line with the percentage that stated that they bought wood pellets from distributors or equipment installers, as these services can often present transportation as an additional extra for the customer, who most likely does not mind paying a little more to avoid all the necessary logistics. 


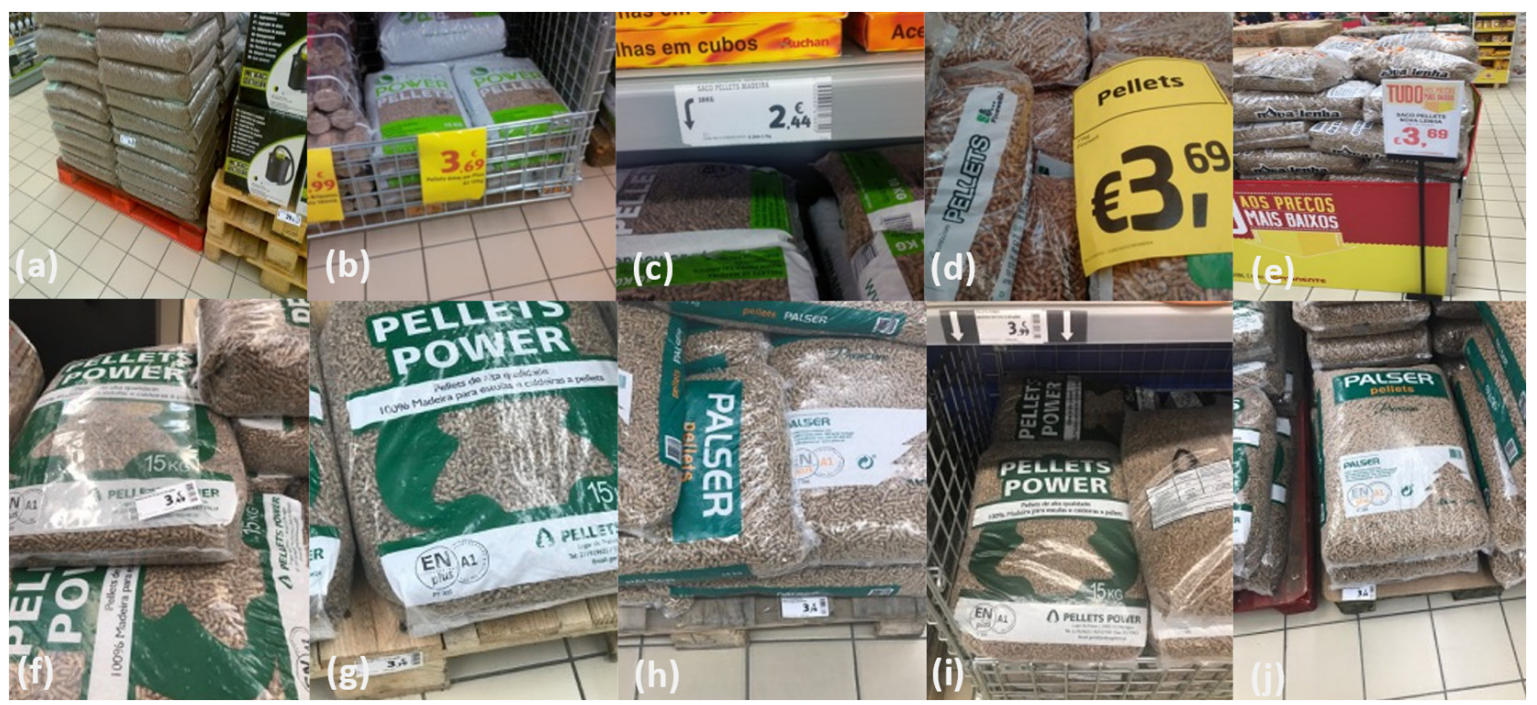

Figure 6. Examples of wood pellets for sale in supermarkets. The images were obtained from large commercial surfaces in the northern region of mainland Portugal in the period between 2014 and 2021. (a) Bag collected in 29/10/2014, with the price of 3.69 EUR; (b) Bag collected in 08/12/2015, with the price of 3.69 EUR; (c) Bag collected in 20/09/2016, with the price of 2.99 EUR; (d) Bag collected in 01/11/2017, with the price of 3.69 EUR; (e) Bag collected in 26/12/2017, with the price of 3.69 EUR; (f) Bag collected in 31/10/2018, with the price of 3.69 EUR; (g) Bag collected in 28/10/2019, with the price of 3.79 EUR; (h) Bag collected in 08/03/2020, with the price of 3.79 EUR; (i) Bag collected in 30/11/2020, with the price of 3.99 EUR; and (j) Bag collected in 23/07/2021, with the price of 3.99 EUR.

Figure 7 shows the distribution of the results obtained regarding which fuel was used for the same purpose before wood pellets.

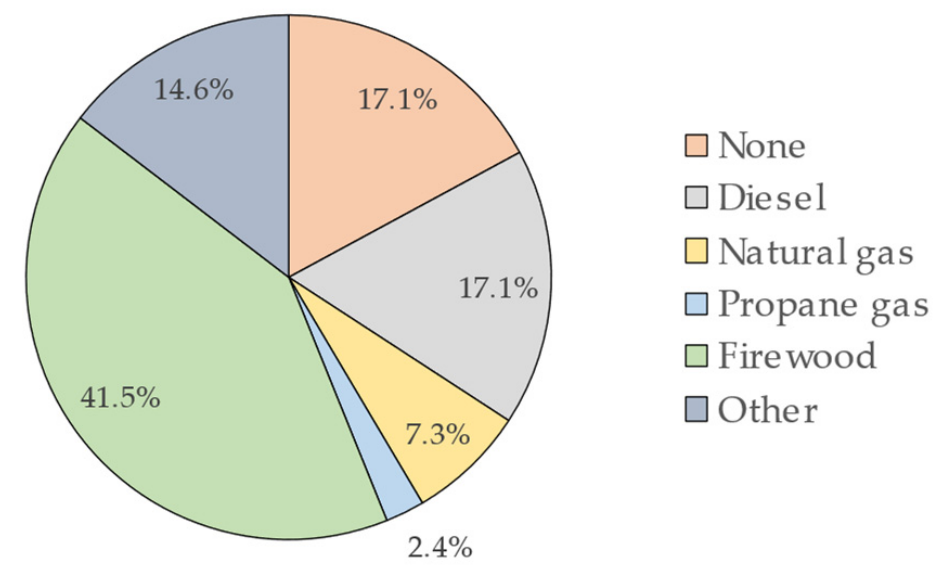

Figure 7. Distribution of results regarding the type of fuel used before wood pellets.

The most significant number of consumers, with $41.5 \%$, referred that firewood was the preferred fuel replaced. This replacement was most likely not related to the price factor, since firewood also has competitive values, and many users even have access to firewood without purchasing it. However, all the logistics associated with the purchase of firewood and its subsequent use make many users opt for an easier and cleaner solution that also has obvious advantages in the matter of its storage. Diesel, traditionally the most used fuel, together with firewood, presented the next value, with $17.1 \%$. In this case, the economic factor was decisive, since in recent years there has been a permanent rise in the price of diesel, even heating diesel, which has a subsidized price. The environmental issue likely also had some weight, especially among consumers aware of sustainability issues and ecological footprint reduction. Propane gas users, representing $2.4 \%$ of respondents, likely followed the same principle as diesel users, as the price of propane gas has also risen 
significantly, in addition to presenting logistical issues like those of diesel distribution. Natural gas users, representing $7.3 \%$ of respondents, who opted for the use of wood pellets must have followed the environmental factor, as from an economic point of view, natural gas is also competitive, and from a logistical point of view, it also has advantages, since the national natural gas network has a high coverage rate in the territory. A group of consumers stated that they used other fuels than the options presented, with $14.6 \%$ of the responses. As to what this fuel would be, they indicated biomass briquettes as the fuel replaced. This type of biomass fuel, available on the domestic market for many years, mainly produced as a byproduct of the furniture and wooden flooring industries, has always been a fuel used as a substitute for firewood, mainly by urban and occasional users, who used this form of densified wood in stoves or fireplaces. About $17.1 \%$ of respondents said they had no previous type of heating system, so they did not have a history regarding the use of any fuel.

As this market is still relatively recent, especially in countries in Central and Northern Europe, Portuguese consumers answered the question about the savings achieved with wood pellets with a certain degree of ignorance, as more than $60 \%$ responded that they did not know. The remaining $40 \%$ were divided between those who responded qualitatively, stating that savings were high, and those who risked a comparative percentage of around 30 to $60 \%$ savings. Most likely, this group that is aware of the savings achieved was related to the consumers who replaced diesel with wood pellets, since it is straightforward to compare the consumption of diesel and wood pellets, typically using a ratio of $2 \mathrm{~kg}$ of wood pellets to one liter of diesel.

Figure 8 presents the results obtained regarding consumers' prevailing criteria for purchasing wood pellets.

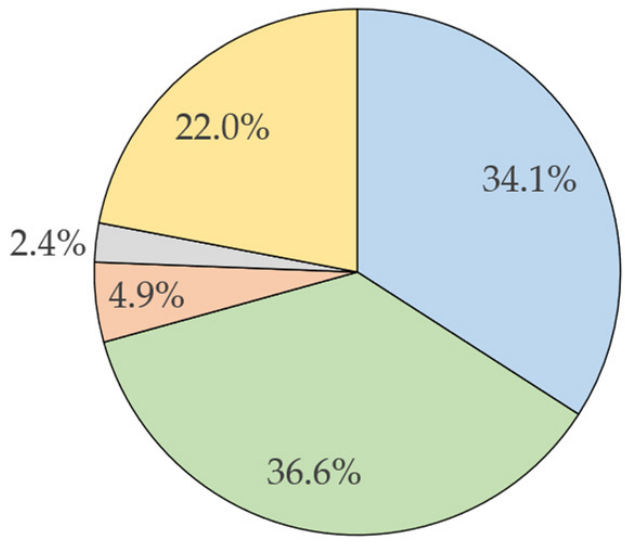

Price

$\square$ Quality of the product

Certification of the product

Proximity of the supplier

$\square$ Other

Figure 8. Distribution of responses on criteria related to the purchase of wood pellets.

As shown in Figure 8, there were two dominant criteria in the universe of responses obtained. On one hand, $36.6 \%$ of respondents answered that product quality was the most relevant criterion, demonstrating consumers' evolution regarding the knowledge they acquire about the different types of products available on the market. However, there was also a strong probability that these consumers had problems caused by the use of poor-quality wood pellets, and for this reason, they elected the quality criterion as the most important when purchasing more fuel. On the other hand, $34.1 \%$ of the consumers surveyed chose price as the most relevant criterion. This group may represent two distinct groups of consumers with different usage profiles. The first may be related to frequent users, but not continuous users, for whom the amount consumed is small and any adverse effect, such as ash sintering, excessive ash production or equipment corrosion, is noticed only after a long time. The second group may be related to intensive users who are knowledgeable about products and equipment and who ensure their maintenance and cleaning, thus avoiding problems. This group would make the most of the lowest-priced fuels, even when the quality and yield are not the best. Other groups presented other 
criteria; $4.9 \%$ answered that their preferential criterion was product certification, which may be a group of users with little knowledge of the products and equipment who assume that certification guarantees the quality of fuels. This use avoids losing guarantees given by the equipment manufacturers and installers. Another group, comprising $2.4 \%$ of respondents, stated that the proximity of the supplier was the main argument to be considered at the time of purchase. These consumers gave more importance to comfort and logistics than to price, preferring that acquisition give them as little work as possible. On the other hand, $22 \%$ affirmed that the criteria were others besides those listed: ease of storage, hygiene and convenience associated with the entire process.

Of all respondents, $84.3 \%$ answered that they had no preference for any brand, while $15.7 \%$ said that they preferred a particular brand. However, this preference was most likely more related to the place of purchase, for example, a specific commercial area, as it is common for consumers to associate two brands, with that in the commercial area always being the dominant one. In other words, the customer, in principle, would not notice the difference if the fuel brand were changed, as commercial areas usually maintain the same framing and layout.

Regarding the properties related to product quality, the results were well-distributed$33.3 \%$ of respondents pointed to the calorific value, $29.8 \%$ chose the ash content and $33.3 \%$ pointed to other causes, such as the compared quality of several parameters and the production of smoke and odors, as being the most important (Figure 9). A small group, with $3.7 \%$, pointed to chlorine content as the most critical parameter. However, as it is a more technical parameter and unknown to most common users, this was likely a group of more knowledgeable consumers with technical capacity.

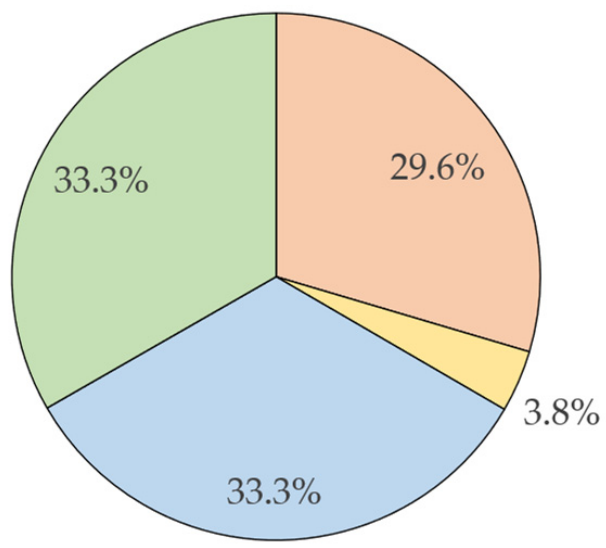

Ashes content

$\square$ Chlorine content

Heating value

$\square$ Other

Figure 9. Distribution of responses on the quality parameters of wood pellets.

Regarding the relationship with commercial brands available on the market, as already seen, there was not exactly a relationship of loyalty with consumers. Thus, it was common that consumers changed brands over time. They did not look for a brand but accepted the available one. However, when asked what parameters they observed when purchasing a unique brand, $59.3 \%$ of consumers said that visible powder in the bag was the most crucial characteristic, $11.1 \%$ said that the color of the pellets was the most critical factor and $7.4 \%$ referred to the size of the pellets in the bag. For $22.2 \%$, none of the characteristics above were essential; some of these respondents pointed out as alternative parameters the fact that wood pellets were sold in a paper bag instead of a plastic bag, while others tended to compare the properties declared by the brands.

Product certification seemed to be a determining factor in consumer confidence in a particular brand, as $74.1 \%$ of respondents said that they preferred to buy certified wood pellets, while $25.9 \%$ said they did not. Once again, it may be inferred that certification was seen as a criterion that somehow guarantees the quality of the products. 


\subsection{Wood Pellet Producers}

It is not easy to accurately assess the national production of wood pellets, as there are some difficulties in obtaining exact values of the effective production of each industrial unit. This is something that producers do not usually provide, which was the main reason for refusing to respond to this survey. For this reason, to assess national production, a calculation was carried out by estimation. Thus, based on the data provided by EUROSTAT (Available online: http:/ / ec.europa.eu (accessed on 30 September 2021)), information on quantities of wood pellets exported from Portugal since the year 2011 is presented in Table 7.

Table 7. Annual quantity of wood pellets exported by Portugal (in tons).

\begin{tabular}{lc}
\hline Year & Exported Quantity (t) \\
\hline 2011 & 535,457 \\
2012 & 603,000 \\
2013 & 818,981 \\
2014 & 797,422 \\
2015 & 693,694 \\
2016 & 621,282 \\
2017 & 513,862 \\
2018 & 611,613 \\
2019 & 729,351 \\
\hline
\end{tabular}

Subsequently, based on data collected from professionals in the sector regarding existing production units, which are presented in Table 8, it was assumed that there might be an overvaluation of the actual production capacities announced. With an alleged installed capacity of almost 1,400,000 $t$ of wood pellets per year, it was assumed that it would be acceptable that effective production should approach $65 \%$ of the figures presented, also based on information collected from experienced professionals in the sector. Thus, the estimated value for the average effective annual production was assumed to approach $906,100 \mathrm{t}$.

In this way, an estimated calculation for the evaluation of internal consumption was performed through the difference between the adequate production capacity $(906,100 \mathrm{t} /$ year $)$ and the average annual quantity exported $(658,296 \mathrm{t} /$ year $)$, which pointed to an annual internal consumption of 247,804 tons. In other words, with the adequate productive capacity that the country currently has, domestic consumption already represents approximately $27 \%$, which is a significant portion. However, it is not easy to distinguish between domestic and industrial consumption, since tracking the type of consumption after sale becomes challenging. For example, Nunes et al. [54,56-59] presented and characterized some of the uses of biomass-derived fuels in the textile industry. Given the growth that has been seen in the installation of sizeable thermal conversion equipment, namely steam boilers, in many industrial sectors, it is likely that national consumption will shift towards the industrial sector. The increase in domestic consumption in recent years has also led to renewed interest from industrial investors. After a period in which it was thought that there would be no place for the development of new large industrial projects, several new projects are currently under construction, with an increase in the national productive capacity of around $20 \%$. 
Table 8. List of production units and installed production capacity.

\begin{tabular}{|c|c|c|c|}
\hline Company Name & Status & Location & Capacity ( $t /$ year) \\
\hline Melpellets & Active & Melgaço & 12,000 \\
\hline Stellep & Active & Chaves & 50,000 \\
\hline Biodensa & Active & Celorico de Basto & 25,000 \\
\hline Tecpellets & Active & Famalicão & 125,000 \\
\hline Glowood & Active & Cercal & 100,000 \\
\hline Martos & Active & Leiria & 30,000 \\
\hline Reginacork & Active & Palmela & 35,000 \\
\hline Ocean Pellets & Inactive & Ribeira Grande & 3000 \\
\hline Pinewells & Active & Arganil & 125,000 \\
\hline Nutriaguiar & Active & Vila Pouca de Aguiar & 10,000 \\
\hline Enerpellets & Active & Pedrogão Grande & 75,000 \\
\hline Pellets Power I & Active & Mortágua & 100,000 \\
\hline Pellets Power II & Active & Alcácer do sal & 90,000 \\
\hline Biohot Energia & Active & Lousada & 75,000 \\
\hline Vimasol & Active & Celorico de Basto & 12,000 \\
\hline JAF & Active & Oleiros & 90,000 \\
\hline Palser & Active & Sertã & 60,000 \\
\hline Enermontijo & Unknown & Pegões & 60,000 \\
\hline Pelletsfirst & Active & Alcobaça & 100,000 \\
\hline Biomad & Active & Guimarães & 10,000 \\
\hline Castro and Filhos & Active & Guimarães & 10,000 \\
\hline ATGreen & In construction & Guarda & 180,000 \\
\hline Futerra & Active & Valongo & 90,000 \\
\hline Pellets do Rodão Lda & Disabled & Vila Velha de Rodão & Unknown \\
\hline YGE as & Disabled & Oliveira de Azeméis & Unknown \\
\hline Biobriquette & Disabled & Penacova & Unknown \\
\hline Soltotal & Active & Montemor-o-Velho & 6000 \\
\hline Green Edge & Active & Cuba & 12,000 \\
\hline Delitimbers & In construction & Proença-a-Nova & Unknown \\
\hline Aleatory Concept & Active & Penacova & 15,000 \\
\hline Briquettes Raro & Active & Vila Nova de Gaia & 50,000 \\
\hline Smartfire & Active & Albergaria-a-Velha & Unknown \\
\hline Sanitop & Active & Viana do Castelo & Unknown \\
\hline Carvoaveiro & Active & Ílhavo & Unknown \\
\hline OZ Energia Pellets & Active & Lisboa & Unknown \\
\hline Siro & Active & Mira & 12,000 \\
\hline $\mathrm{XPZ}$ & Disabled & Esposende & Unknown \\
\hline Four Pellets & Disabled & Barcelos & Unknown \\
\hline Ambipellets & Disabled & Póvoa de Lanhoso & Unknown \\
\hline Thermowall II & Disabled & Braga & Unknown \\
\hline Nicepellets & Disabled & Ílhavo & Unknown \\
\hline CMC & Active & Alcobaça & 15,000 \\
\hline
\end{tabular}

Of the 46 contacts made asking producers/distributors to reply to the questionnaire, only 6 responded. Of the remaining 40,11 responded by stating that they would not do so because of confidentiality regarding data of a commercial nature, while the remaining $29 \mathrm{did}$ not provide any response. Thus, in the responses obtained, all respondents claimed to be producers that used their brand but also, in two situations, produced with customer brands or even white labels. The answers obtained also allowed confirming, or even correcting, the data referring to the installed production capacity. Five of the respondents said they had ENPlus ${ }^{\circledR}$ certificates, and four indicated that they had other certifications, such as the ISO 9001 standard. Industrial pellets dominated their production. All respondents had different packaging options ( $15 \mathrm{~kg}$ bag, big bags and bulk), and they all exported, with the percentage of product destined for the domestic market varying between 10 and $75 \%$. All respondents claimed that they used only Pinus pinaster wood as a raw material to produce wood pellets. However, consulted forest management companies stated that despite the 
preference for Pinus pinaster, both Eucalyptus globulus and species of the genus Acacia (Acacia dealbata and Acacia melanoxylon) are used in significant quantities. The respondents presented different values for industrial and domestic pellets regarding the practiced sales prices, as shown in Table 9.

Table 9. Evolution of prices charged by domestic producers in 2016, 2017, 2018 and 2019 (average values presented by respondents in EUR/ton).

\begin{tabular}{lcccc}
\hline & 2016 & 2017 & 2018 & 2019 \\
\hline Industrial wood pellets & $116 \mathrm{EUR} / \mathrm{t}$ & $105 \mathrm{EUR} / \mathrm{t}$ & $108 \mathrm{EUR} / \mathrm{t}$ & $112 \mathrm{EUR} / \mathrm{t}$ \\
Domestic wood pellets & $150 \mathrm{EUR} / \mathrm{t}$ & $155 \mathrm{EUR} / \mathrm{t}$ & $160 \mathrm{EUR} / \mathrm{t}$ & $165 \mathrm{EUR} / \mathrm{t}$ \\
\hline
\end{tabular}

The figures presented may suffer sharp fluctuations throughout the different seasons and from producer to producer, since only a tiny number of producers were willing to participate in the survey. However, they seemed to be in line with the values found in the market, especially for domestic wood pellets. Regarding industrial wood pellets, almost entirely destined for export, the values obtained seemed to follow the trend verified in Argus Biomass (Available online: http:/ / www.argusmedia.com (accessed on 30 September 2021)). The same index showed a clear upward trend in prices for the years 2022 and 2023, which may reach $17 \%$ and $23 \%$, respectively, compared to the FOB values for Portugal foreseen for the year 2021.

\subsection{Market Analysis}

The results obtained in this study demonstrated an evolution of the Portuguese market, like what happened in similar markets. However, the Portuguese market has some singularities related both to the conditions associated with its geographic location, which enhances the production of forest biomass, and the fact that it has started the process of creating a market essentially focused on export. Creating an internal market was a slow process, full of ups and downs, with national producers of wood pellets always preferring, at an initial stage, to export their products to more mature markets willing to pay a premium for Portuguese wood pellets. Although this beginning focused on another direction, the domestic market was slowly being created and, above all, consolidated.

As can be seen from the results obtained, there is recognition of the product and its advantages. Consumers have also acquired critical skills about the different products available. This market is starting to attain a certain level of demand, with consumers preferring certified products, mainly because of the guarantee of quality. Despite a slight upward trend in prices in recent years, prices remain stabilized, and it is foreseeable that they will remain at values close to the current ones, since although there is an increase in demand, there is a large installed productive capacity, so producers will be able to place larger quantities on the domestic market and in this way stabilize prices. It should be noted, however, that this is a product for which the final price is directly and primarily dependent on the purchase price of the raw material, so it is essential to permanently monitor the price of forest raw materials from the perspective of forecasting the evolution of prices to avoid surprises to the market. Thus, the Portuguese market for wood pellets may be considered a relatively mature market that still presents a significant growth margin, partly in the residential sector but mainly in the semi-industrial and industrial sectors, which, although they usually do not pay values as high as the residential/domestic sector, consume much larger quantities per customer and, above all, do not suffer from the seasonality characteristic of most residential-type consumers, who consume wood pellets during the months of fall and winter.

\section{Conclusions}

Portugal is a wood pellet producer that has grown in its production capacity and internal consumption, with the increment verified by domestic consumers, mainly in recent 
years. The use of wood pellets has become usual, and the market is currently growing. As inferred from the results obtained in the survey, Portuguese consumers seek to satisfy their needs by searching for quality products at the best price. The wood pellet market can be considered mature, with consumers demonstrating a certain degree of knowledge about the products and their uses. It is a market presenting growing requirements, especially regarding the efficiency of thermal conversion equipment and damage caused using products with high levels of chlorine, alkali metals, silica or ash. The Portuguese wood pellet market is growing, both from a production and a consumption perspective, benefiting from the favorable conditions that the country presents, namely the abundance of forest resources and a geographic location that favors export. This export capacity is facilitated by seaport areas already prepared to handle this type of material and the experience acquired in the past 15 years of activity that the sector has carried out in Portugal. As the wood pellet market is dynamic and in permanent evolution, researchers must continue to collect data to allow assessing the permanent state of the market. It is expected that new brands can replace the current ones, even from the perspective of updating the brands themselves, and that references can be used to the incorporation of residual biomass in the production of wood pellets, highlighting the contribution to the circular economy of this industry, seeking the loyalty of a group of consumers who are increasingly concerned about the environmental problems that affect the planet.

Author Contributions: Conceptualization, M.C., M.F.D. and L.J.R.N.; methodology, M.F.D. and L.J.R.N.; validation, M.C., M.F.D. and L.J.R.N.; formal analysis, M.C., M.F.D. and L.J.R.N.; investigation, M.C., M.F.D. and L.J.R.N.; resources, M.F.D. and L.J.R.N.; data curation, M.C., M.F.D. and L.J.R.N.; writing — original draft preparation, M.C., M.F.D. and L.J.R.N.; writing—review and editing, M.F.D. and L.J.R.N.; visualization, M.C., M.F.D. and L.J.R.N.; supervision, M.F.D. and L.J.R.N.; project administration, M.F.D. and L.J.R.N. All authors have read and agreed to the published version of the manuscript.

Funding: This research was funded by the FCT—Fundação para a Ciência e Tecnologia/MCTES through national funds and, when applicable, cofinanced by the FEDER under the new partnership agreement PT2020, grant number PCIF/GVB/0083/2019. L.J.R.N. was supported by proMetheusResearch Unit on Energy, Materials and Environment for Sustainability-UIDP/05975/2020 and funded by national funds through FCT—Fundação para a Ciência e Tecnologia.

Institutional Review Board Statement: Not applicable.

Informed Consent Statement: Not applicable.

Data Availability Statement: Data are available per on request to the corresponding author.

Acknowledgments: The author declare no further acknowledgments.

Conflicts of Interest: The authors declare no conflict of interest.

\section{References}

1. Bang, G. Energy security and climate change concerns: Triggers for energy policy change in the United States? Energy Policy 2010, 38, 1645-1653. [CrossRef]

2. Bilen, K.; Ozyurt, O.; Bakırc1, K.; Karslı, S.; Erdogan, S.; Yılmaz, M.; Comaklı, O. Energy production, consumption, and environmental pollution for sustainable development: A case study in Turkey. Renew. Sustain. Energy Rev. 2008, 12, $1529-1561$. [CrossRef]

3. Balat, M.; Ayar, G. Biomass energy in the world, use of biomass and potential trends. Energy Sour. 2005, 27, 931-940. [CrossRef]

4. Bildirici, M.E. Economic growth and biomass energy. Biomass Bioenergy 2013, 50, 19-24. [CrossRef]

5. Field, C.B.; Campbell, J.E.; Lobell, D.B. Biomass energy: The scale of the potential resource. Trends Ecol. Evol. 2008, 23, 65-72. [CrossRef] [PubMed]

6. Kopetz, H. Build a biomass energy market. Nature 2013, 494, 29-31. [CrossRef] [PubMed]

7. Searcy, E.; Flynn, P.; Ghafoori, E.; Kumar, A. The relative cost of biomass energy transport. Appl. Biochem. Biotechnol. 2007, 137, 639-652. [PubMed]

8. Herbert, G.J.; Krishnan, A.U. Quantifying environmental performance of biomass energy. Renew. Sustain. Energy Rev. 2016, 59, 292-308. [CrossRef] 
9. Hohenstein, W.G.; Wright, L.L. Biomass energy production in the United States: An overview. Biomass Bioenergy 1994, 6, 161-173. [CrossRef]

10. Hall, D.O. Biomass energy. Energy Policy 1991, 19, 711-737. [CrossRef]

11. Jåstad, E.O.; Bolkesjø, T.F.; Trømborg, E.; Rørstad, P.K. The role of woody biomass for reduction of fossil GHG emissions in the future North European energy sector. Appl. Energy 2020, 274, 115360. [CrossRef]

12. Dominković, D.F.; Bačeković, I.; Ćosić, B.; Krajačić, G.; Pukšec, T.; Duić, N.; Markovska, N. Zero carbon energy system of South East Europe in 2050. Appl. Energy 2016, 184, 1517-1528. [CrossRef]

13. Nunes, L.; Matias, J.; Catalão, J. A review on torrefied biomass pellets as a sustainable alternative to coal in power generation. Renew. Sustain. Energy Rev. 2014, 40, 153-160. [CrossRef]

14. Ilieva, J.; Baron, S.; Healey, N.M. Online surveys in marketing research. Int. J. Mark. Res. 2002, 44, 1-14. [CrossRef]

15. Van Selm, M.; Jankowski, N.W. Conducting online surveys. Qual. Quant. 2006, 40, 435-456. [CrossRef]

16. Lefever, S.; Dal, M.; Matthíasdóttir, Á. Online data collection in academic research: Advantages and limitations. Br. J. Educ. Technol. 2007, 38, 574-582. [CrossRef]

17. Keusch, F. Why do people participate in Web surveys? Applying survey participation theory to Internet survey data collection. Manag. Rev. Q. 2015, 65, 183-216.

18. Mellis, A.M.; Bickel, W.K. Mechanical Turk data collection in addiction research: Utility, concerns and best practices. Addiction 2020, 115, 1960-1968. [CrossRef] [PubMed]

19. Dillman, D.A. Mail and Internet Surveys: The Tailored Design Method-2007 Update with New Internet, Visual, and Mixed-Mode Guide; John Wiley \& Sons: Hoboken, NJ, USA, 2011.

20. Swietochowski, A.; Dabrowska, M.; Lisowski, A. Friction properties of pellets made of wood and straw. Eng. Rural Dev. 2018. [CrossRef]

21. Maliga, G.; Patil, A. The aspects of combustion and co-combustion biomass. Nat. Gas 1824, 228, 33.

22. Ahn, Y.; Chen, Y.; Chen, H.; Helm, R.; Nelson, E.; Shields, K.; Stringer, R.; Bailie, R. Research and Evaluation of Biomass Resources/Conversion/Utilization Systems (Market/Experimental Analysis for Development of a Data Base for a Fuels from Biomass Model); Quarterly Technical Progress Report; 1 November 1979-31 January 1980; Gilbert Associates, Inc.: Reading, PA, USA, 1980.

23. Hathaway, S.A.; Lin, J.; Mahon, D.; Magrino, T.; Duster, K. Densified Biomass as an Alternative Army Heating and Power Plant Fuel; Construction Engineering Research Lab (Army): Champaign, IL, USA, 1980.

24. Haase, S. The Program. Wood Pellet Manufacturing in Colorado: An Opportunity Analysis: Final Report. 1993. Available online: https://books.google.com/books?id=-Ec_AAAAMAAJ\&printsec=frontcover\#v=onepage\&q\&f=false (accessed on 18 October 2021).

25. Bentzen, J.; Smith, V.; Dilling-Hansen, M. Sustainable Energy Supply in Rural Areas: Availability and Competitivity in the Danish Wood Pellet Branch; Bruun og Soerensen Energiteknik A/S: Aarhus, Denmark, 1996.

26. Aruna, P.; Laarman, J.G.; Araman, P.A.; Cubbage, F. An analysis of wood pellets for export: A case study of Sweden as an importer. For. Prod. J. 1997, 47, 49-52.

27. Hillring, B.; Vinterback, J. Wood pellets in the Swedish residential market. For. Prod. J. 1998, 48, 67.

28. Hillring, B. Regional prices in the Swedish wood-fuel market. Energy 1999, 24, 811-821. [CrossRef]

29. Hillring, B. The Swedish wood fuel market. Renew. Energy 1999, 16, 1031-1036. [CrossRef]

30. Hugues, J. The pellet stoves market in USA. Bois Energ. 1999.

31. Roos, A.; Graham, R.L.; Hektor, B.; Rakos, C. Critical factors to bioenergy implementation. Biomass Bioenergy 1999, 17, 113-126. [CrossRef]

32. Vinterbäck, J. Wood Pellet Use in Sweden: A Systems Approach to the Residential Sector. Ph.D. Thesis, Deptartment of Forest Management and Products, Swedish University of Agricultural Sciences, Uppsala, Sweden, 2000.

33. Cotton, R.; Giffard, A. Introducing Wood Pellet Fuel to the UK; Renewable Heat and Power Ltd.: Crown, UK, 2001.

34. Alakangas, E.; Paju, P. Wood Pellets in Finland-Technology, Economy and Market; OPET Report 5; OPET Finland: Helsinki, Finland, 2002.

35. Madlener, R.; Gustavsson, L. Socio-Economics of the Diffusion of Innovative Bioenergy Technologies: The Case of Small Pellet Heating Systems in Austria. Soc.-Econ. Asp. Bioenergy Syst. 2003.

36. Kaygusuz, K.; Türker, M. Biomass energy potential in Turkey. Renew. Energy 2002, 26, 661-678. [CrossRef]

37. Mölder, A. Heating System Analysis in Jogeva District, Estonia. 2003. Available online: https://www.theseus.fi/bitstream/handle/ 10024/20539/aino_nro1.pdf?sequence=3\&isAllowed=y (accessed on 18 October 2021).

38. Bartolelli, V.; Cantarella, M.; Caserta, G.; Viparelli, P. European Bioenergy Networks Biomass; Country Report of ITALY; ITABIA: Roma, Italy.

39. Aleksandrova, N.B. Characteristics of Creation of the Wood Pellets Market in Russia. J. Sib. Fed. Univ. Humanit. Soc. Sci. 2008, 1, 443-454.

40. Wang, C.; Yan, J. Feasibility analysis of wood pellets production and utilization in China as a substitute for coal. Int. J. Green Energy 2005, 2, 91-107. [CrossRef]

41. Yagi, K.; Nakata, T. Economics and a policy option on wood pellet fuel in Japan. J. Jpn. Inst. Energy 2006, 85, 451-460. [CrossRef]

42. Tarasov, D. Wood Pellet Markets in Russia. 2009. Available online: https://insurance.cms-lists.org/host-https-lutpub.lut.fi/ handle/10024/45518 (accessed on 18 October 2021). 
43. Rakitova, O.; Ovsyanko, A.; Sikkema, R.; Junginger, M. Wood Pellets Production and Trade in Russia, Belarus E Ukraine; Pelletsatlas: Market Research Report WP; 2009; Available online: https://www.researchgate.net/publication/273256481_Wood_Pellets_ Production_and_Trade_in_Russia_Belarus_Ukraine (accessed on 18 October 2021).

44. Mikołajczak, E. The analysis of pellet market in Poland. Ann. Wars. Univ. Life Sci.-SGGW For. Wood Technol. 2009, 69, 65-70.

45. Pigaht, M.; Janssen, R.; Passalacqua, F.; Zaetta, C.; Grassi, G.; Sandovar, A.; Vegas, L.; Tsoutsos, T.; Karapanagiotis, N.; Fjällström, T. Pellets in Southern Europe-New Resources, New Products, New Markets. 2004. Available online: http:/ / www.cres.gr/pellets/ index_files/pdf/Paper_2004_01_29\%20wip-munich\%20de.pdf (accessed on 18 October 2021).

46. Passalacqua, F.; Zaetta, C. Pellets in Southern Europe. The state of the art of pellets utilisation in Southern Europe. New perspectives of pellets from agri-residues. In Proceedings of the Proceedings of the 2nd World Conference on Biomass for Energy, Industry and Climate Protection, Rome, Italy, 10-14 May 2004.

47. Laschi, A.; Marchi, E.; González-García, S. Environmental performance of wood pellets' production through life cycle analysis. Energy 2016, 103, 469-480. [CrossRef]

48. Smith, T.P.; Junginger, H.M. Analysis of the global production location dynamics in the industrial wood pellet market: An MCDA approach. Biofuels Bioprod. Biorefin. 2011, 5, 533-547. [CrossRef]

49. Sjølie, H.K.; Solberg, B. Greenhouse gas emission impacts of use of Norwegian wood pellets: A sensitivity analysis. Environ. Sci. Policy 2011, 14, 1028-1040. [CrossRef]

50. Xian, H.; Colson, G.; Mei, B.; Wetzstein, M.E. Co-firing coal with wood pellets for US electricity generation: A real options analysis. Energy Policy 2015, 81, 106-116. [CrossRef]

51. Monteiro, E.; Mantha, V.; Rouboa, A. The feasibility of biomass pellets production in Portugal. Energy Sour. Part B Econ. Plan. Policy 2013, 8, 28-34. [CrossRef]

52. Monteiro, E.; Mantha, V.; Rouboa, A. Portuguese pellets market: Analysis of the production and utilization constrains. Energy Policy 2012, 42, 129-135. [CrossRef]

53. Nunes, L.; Matias, J.; Catalão, J.P. Economic and sustainability comparative study of wood pellets production in Portugal, Germany and Sweden. In Proceedings of the International Conference on Renewable Energies and Power Quality, Cordoba, Spain, 8-10 April 2014; pp. 526-531.

54. Nunes, L.; Matias, J.C.; Catalao, J.P. Wood pellets as a sustainable energy alternative in Portugal. Renew. Energy 2016, 85, 1011-1016. [CrossRef]

55. Lopes, S.I.; Nunes, L.J.; Curado, A. Designing an Indoor Radon Risk Exposure Indicator (IRREI): An Evaluation Tool for Risk Management and Communication in the IoT Age. Int. J. Environ. Res. Public Health 2021, 18, 7907. [CrossRef] [PubMed]

56. Nunes, L.J.; Matias, J.C.; Catalao, J.P. Application of biomass for the production of energy in the Portuguese textile industry. In Proceedings of the 2013 International Conference on Renewable Energy Research and Applications (ICRERA), Madrid, Spain, 20-23 October 2013; pp. 336-341.

57. Nunes, L.; Matias, J.; Catalão, J. Analysis of the use of biomass as an energy alternative for the Portuguese textile dyeing industry. Energy 2015, 84, 503-508. [CrossRef]

58. Nunes, L.J.; Godina, R.; Matias, J.C.; Catalão, J.P. Economic and environmental benefits of using textile waste for the production of thermal energy. J. Clean. Prod. 2018, 171, 1353-1360. [CrossRef]

59. Nunes, L.J.R.; Godina, R.; Matias, J.C.d.O. Technological innovation in biomass energy for the sustainable growth of textile industry. Sustainability 2019, 11, 528. [CrossRef] 